\title{
SCIENTOMETRIC ANALYSIS OF RESEARCH FROM A FEMINIST PERSPECTIVE
}

\author{
MARÍA DEL ROCÍO HERNÁNDEZ-POZO* \\ NATIONAL AUTONOMOUS UNIVERSITY OF MEXICO, REGIONAL CENTER OF MULTIDISCIPLINARY RESEARCH, \\ EQUITY AND GENDER PROGRAM, CUERNAVACA, MORELOS, MEXICO \\ NATIONAL AUTONOMOUS UNIVERSITY OF MEXICO, FES IZTACALA, HUMAN LEARNING RESEARCH PROJECT, \\ TLALNEPANTLA, ESTADO DE MEXICO, MÉXICO \\ LOURDES ELENA FERNÁNDEZ RIUS \\ UNIVERSITY OF LA HABANA, SCHOOL OF PSYCHOLOGY, LA HABANA, CUBA \\ GUEST RESEARCHER AT THE NATIONAL AUTONOMOUS UNIVERSITY OF MEXICO, CENTER OF INTERDISCIPLINARY \\ STUDIES IN SCIENCE AND HUMANITIES, MEXICO, D. F., MEXICO
}

Recibido, septiembre 1/2013

Concepto evaluación, octubre 2/2013

Aceptado, noviembre 20/2013
Referencia: Hernández-Pozo, M. R., \& Fernández-Rius, L. E. (2013). Scientometric analysis of research from a feminist perspective. Acta Colombiana de Psicología, $16,(2), 31-46$

\begin{abstract}
In order to build a historical map of scientific production from a feminist perspective and to analyze the central themes that have been studied by the academics from this approach, a search was conducted using SCOPUS an international bibliometric database, for the period between 1960 and July 2013. The search strategy based on the use of four key words produced 54 articles, written by 86 specialists of 14 countries, among them USA, UK, Canada and Australia, 87\% written in English and 4\% in Spanish. Even though the feminist theoretical approach is interdisciplinary by definition, the main disciplines represented in the sample were social sciences and Psychology. $69 \%$ of the articles were written by a single author, and $78 \%$ of the authors were women. Citation varied between 137 and zero. The most cited studies were from Canada, USA and the UK. Articles covered a wide variety of themes emphasizing theoretical, methodological and empirical issues in different areas of knowledge. Additionally a very low presence of articles dealing with the impact of the feminist perspective in public policies was observed, as well as very few articles devoted to examine applications of the feminist theory on education. Conclusions highlight the challenge for Latin American feminist researchers to increase their presence in scientific journals with international distribution indexed in SCOPUS, and to increase the quality of specialized Hispanic journals, in order to favor scientific dissemination on the subject in Spanish. Key words: Scientometrics, feminist perspective, SCOPUS, distribution of authors by sex.
\end{abstract}

\section{ANÁLISIS CIENCIOMÉTRICO DE INVESTIGACIONES CON PERSPECTIVA FEMINISTA}

\begin{abstract}
Resumen
Con el fin de construir un mapa histórico de la producción científica con perspectiva feminista y analizar los temas que han ocupado la atención de los académicos a partir de ese enfoque, se realizó una búsqueda en la base bibliométrica SCOPUS, del periodo comprendido entre 1960 y julio del 2013. La búsqueda, a partir de cuatro palabras clave, arrojó 54 artículos, escritos por 86 especialistas de 14 países, de los cuales se destacaron: Estados unidos, Inglaterra, Canadá y Australia. 87\% de ellos estaban escritos en inglés y $4 \%$ en español, con predominanacia de enfoques disciplinarios de ciencias sociales y de psicología, aunque por definición, la teoría feminista trata temas interdisciplinarios. En el $69 \%$ de los casos esos artículos fueron producto de la autoría de una sola persona, y el 78\% de los autores fueron mujeres. La citación osciló entre 137 y cero, siendo los artículos más populares los de origen canadiense, estadounidense e inglés Los artículos reflejan una amplia gama de temáticas que enfatizan aspectos teóricos, metodológicos y empíricos en diferentes áreas del saber. Adicionalmente, se observó una escasa presencia de artículos que abordaran el impacto del feminismo en las políticas públicas, así como de artículos que examinaran aplicaciones de la teoría feminista sobre la educación. Se concluye que un reto para la producción latinoamericana en investigación feminista es aumentar su presencia en revistas científicas de circulación internacional indexadas en SCOPUS, así como elevar la calidad de las revistas hispanoamericanas en el tema, de modo que permita la divulgación científica en español.

Palabras clave: Cienciometría, perspectiva feminista, SCOPUS, distribución de autores por sexo.
\end{abstract}

\footnotetext{
* Dra. María del Rocío Hernández Pozo, rochpoz@co-educa.org Tel.+52-777-3179988
}

1 A preliminary version of this study was presented at the Colloquium "The challenges of feminism in Latin America", June 20 and 21 , 2013, CEIICH-UNAM, Mexico, DF. The authors thank the anonymous reviewers for the comments to improve this paper. Correspondence should be sent to Maria del Rocio Hernandez Pozo, UNAM-CRIM, Equity and Gender Program, Ave. Universidad s/n, Circuito 2, Campus Ciudad Universitaria de la UAEM, Col. Chamilpa, C.P. 62210, Cuernavaca, Morelos, México. herpoz@unam.mx 


\title{
ANÁLISE CIENCIOMÉTRICO DE PESQUISAS COM PERSPECTIVA FEMINISTA
}

\begin{abstract}
Resumo
Com o objetivo de construir um mapa histórico da produção científica com perspectiva feminista e analisar os temas que ocuparam a atenção dos acadêmicos a partir desse enfoque, realizou-se uma busca na base bibliométrica SCOPUS, do período compreendido entre 1960 e julho de 2013. A busca, a partir de quatro palavras chave, mostrou 54 artigos, escritos por 86 especialistas de 14 países, dos quais destacaram-se Estados unidos, Inglaterra, Canadá e Austrália. 87\% deles estavam escritos em inglês e 4\% em espanhol, com predominância de enfoques disciplinares de ciências sociais e de psicologia, ainda que por definição, a teoria feminista trata temas interdisciplinares. Em $69 \%$ dos casos esses artigos foram produto da autoria de uma só pessoa, e 78\% dos autores foram mulheres. A citação oscilou entre 137 e zero, sendo os artigos mais populares os de origem canadense, estadunidense e inglês Os artigos refletem um amplo leque de temáticas que enfatizam aspectos teóricos, metodológicos e empíricos em diferentes áreas do saber. Além disso, observou-se uma rara presença de artigos que abordaram o impacto do feminismo nas políticas públicas, bem como de artigos que examinaram aplicações da teoria feminista sobre a educação. Conclui-se que um desafio para a produção latino-americana em pesquisa feminista é aumentar a sua presença em revistas científicas de circulação internacional indexadas no SCOPUS, bem como elevar a qualidade das revistas hispanoamericanas nesse tema, de modo que permita a divulgação científica em espanhol.

Palavras chave: Cienciometria, perspectiva feminista, SCOPUS, distribuição de autores por sexo.
\end{abstract}

\section{INTRODUCTION}

Research from a feminist perspective has been a milestone in showing a change in the dominant paradigm of social science since the second half of the twenty century.

Feminist theory articulates the reflections of women's struggles for emancipation. An offspring of feminism as a social and political movement, it constitutes thought, reflection, production and conceptual systematization about the causes and foundations of the movement along three centuries. Today it is a theory formed without linearity or homogeneity given the complexity of the phenomenon attempted to be known, elucidated and substantiated. Therefore we cannot speak of a single critical current that is identified as "feminism " in the singular, or as a single feminist theoretical proposal, as there are different characteristics in historical stages known as the "waves" of this movement. However, within feminist theory interconnected axes along history and sociopolitical contexts can be identified with defined conceptual positions arising from feminism.

From an epistemological point of view three distinct positions cab be identified: 1) feminist empiricism, feminist standpoint and feminist postmodernism (Adam , 2006) advocating construction of knowledge considering the feminist perspectives. It is also possible to speak of equality feminism, a feminism of difference, of a radical, postcolonial, socialist feminism, thereby illustrating the diversity of axes that mark feminist thought and research.

The purpose of scientometrics is to generate a quantitative characterization of scientific activity and objectively measure the progress of the disciplines, so keeping a close connection with the sociology of science ( Zitt \& Bassecoulard , 2008). The use of scientometric criteria not only informs the editorial decision-making to improve the quality of journals, promotion and internationalization in order to reach a wider audience ( Aleixandre - Benavent, Valderrama - Zurián \& González- Alcaide, 2007), but also allows the construction of a fairly accurate map of the progress of an area of knowledge .

As Zitt and Bassecoulard (2008) point out the scientometric tools would be particularly useful in addressing the political and social dimensions of scientific communities, providing a detailed analysis of the particular forms of mobility that have occurred in different fields of science, such as diasporas and reversals of diasporas, or studies of social stratification, phenomena that are not foreign to studies with a feminist perspective.

At present there are no scientometric studies of feminist research; however, these studies are essential for understanding this field of knowledge, its historical development, the issues that have focused its attention, those that that have not been addressed yet and to map the scientific output from this theoretical approach.

The central objective of this review was to identify articles with a feminist perspective that appeared in indexed journals in a prestigious international bibliometric base, to make visible the sex of the coauthors, their country of origin, as well as issues and epistemological positions that have chronologically marked the research inspired by feminist theory and to show its impact on the scientific community as measured by the citations received by such studies. 


\section{METHOD}

\section{Scope of the study}

The review of the literature was based on articles published in journals registered on SCOPUS bibliometric basis, in the areas of social sciences and humanities as well as in the health sciences, from the first record of the journals that account that database (1960) up to the consultation date of June 15, 2013.

\section{Instrument}

The bibliometric database SCOPUS, published by the Dutch editorial Elsevier is a database specializing in scientific, technical, medical sciences and social information, including the arts and humanities. SCOPUS covers 29 million abstracts from over 23,600 journals. For the purpose of this research only two of the four areas in which information is looked up by SCOPUS, the area of social sciences and humanities and the area of health sciences, which together cover 11,500 titles of international journals.

On the choice of bibliometric database SCOPUS for conducting this analysis, the selection is justified because it meets five major criteria: 1) is one of the largest bibliometric databases for scientific literature, 2) it updates its collection daily and features a powerful interface that allows fast and accurate searches, 3 ) its coverage is balanced within subject areas and languages included and has a fairly homogeneous global representation for all areas except for arts and humanities, and 4) the criteria for inclusion of journals are strict, similar to Thompson ISI (De Moya- Anegón et al. , 2007).

\section{Procedure}

In order to make a selection of the most relevant articles on the topic a search was performed for published articles that contained the following words in English: "feminist", "perspective", "empirical" and "study". The requirement was that all these words should appear at least once in the sections of title, abstract or keywords of the articles in question.

Search excluded book chapters and presentations at conferences, in order to standardize the criteria for selection of document sources.

Subsequently the sex of the authors of each article was looked up, by means of finding their full name in the SCOPUS database and in case of doubt an independent search was performed for each author with their institution via google internet search engines and / or looking for individual photos at the institutional pages corresponding to their affiliations.
The results of the analysis of the literature during the selected period were organized into three main sections: 1 ) Distribution in terms of chronology, geography, discipline, institution of affiliation and by type of journal, 2) distribution by sex of authors, main author and number of citations, and 3) thematic and collaborative distribution networks.

Chronological and geographical analysis by discipline, institution, language and journal.

In the period from the beginning of the SCOPUS records until June 15, 2013, 54 entries were obtained, the first of which occurred in 1984. From that date, during the first decade just 5 articles were published. The second decade of production on the subject tripled to 17 articles, while so far the productivity of the third decade had risen to 32 items, that is, 6.4 times more than during the first period. Despite some irregularities in production that can be seen in Figure 1, the general trend has been the rise of scientific production on the subject. It is predicted that this pattern of growth in the number of articles with feminist perspective published in this data base will continue in the coming years, based upon the increasing research in this area of study, especially in the last decade, as well as due to the pressure universities and research institutions exert over social scientists to increase their presence in journals of international circulation with high impact indexes.

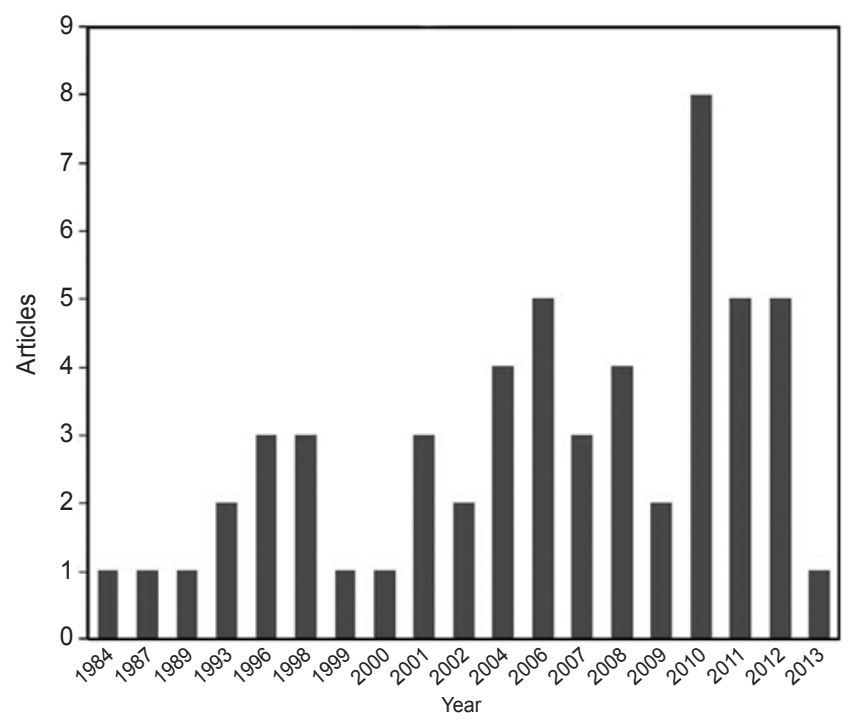

Figure 1. Distribution of articles with feminist perspective published during the analyzed period.

In terms of countries of origin of the articles, 14 countries with different frequencies were detected : USA with 22 articles, England with 8, Canada produced 7 studies, 
Australia with 4, Brazil, Israel and Sweden, with 2 each, and one article from each of the following countries: Austria, Colombia, Denmark, Spain, Japan, Malawi and South Africa (see Table 1).

USA concentrated most scientific output in this mode (40\%). Other countries who excelled individually were England with $14.5 \%$, Canada with $12.7 \%$, and Australia with $7.3 \%$ of the total production. A common denominator of the countries that occupied the top four places was having English as the official language. In addition of being English-speaking countries, all of them were located at the top range of the human development index.

According to the Report of the United Nations Development Program (2013) the countries previously mentioned held the following places in the Human Development Index $(\mathrm{HDI})^{2}$ : .Australia $2^{\text {nd }}$, USA $3^{\text {rd }}$, Canada $11^{\text {th, }}$, and England $26^{\circ}$. This allows reflecting upon the articulation between human development, the dominance of the English language and the scientific production which this study makes evident. On the other hand, USA is one of the pioneering countries in terms of feminist studies with great tradition and scholarship in this regard, which is revealed again in its central presence of publications in this database.

The European region with five countries reached 24\% of the total in the same period. While the Latin American region with two countries achieved $5 \%$ of the total, since only three articles with feminist perspective met the criteria set by SCOPUS journals in the period under study. The count, however, was less flattering to the African and Asian regions, with two and one article respectively, that is, 4 and $2 \%$, respectively.

With respect to the languages in which research feminist perspective is disseminated in journals indexed in SCOPUS, 48 articles were published in English ( 87\%), 2 in Spanish $(4 \%)$, one in German, one in French, one in Japanese and one in Portuguese.

These results complement the previous analysis, precisely because no Spanish speaking country in Latin America had a very high HDI. Only few were classified in the high level and most were rated medium to low, being this latter the case, even more pronounced for African and Asian regions. Thus when referring to a special impact scientific production, it is always in connection with socioeconomic and cultural development. It is also pointed out that English is the predominant language for science dissemination in this area, a fact that reinforces the link mentioned above.
Additionally seven thematic areas were identified for the journals publishing articles under study, which included in descending order: Social Science Research with 43 ( 80\%), Psychology with 11 ( $20 \%$ ), Nursing, with seven (13\%), Medicine, with five (9\%), Accounting and Management, with four ( 7\%), Arts and Humanities, with three (5\%), Economics, Econometrics and Finance with one, and the health professions also with one. Note that each article could have more than one subject area. Figure 2 shows the distribution of articles by subject area.

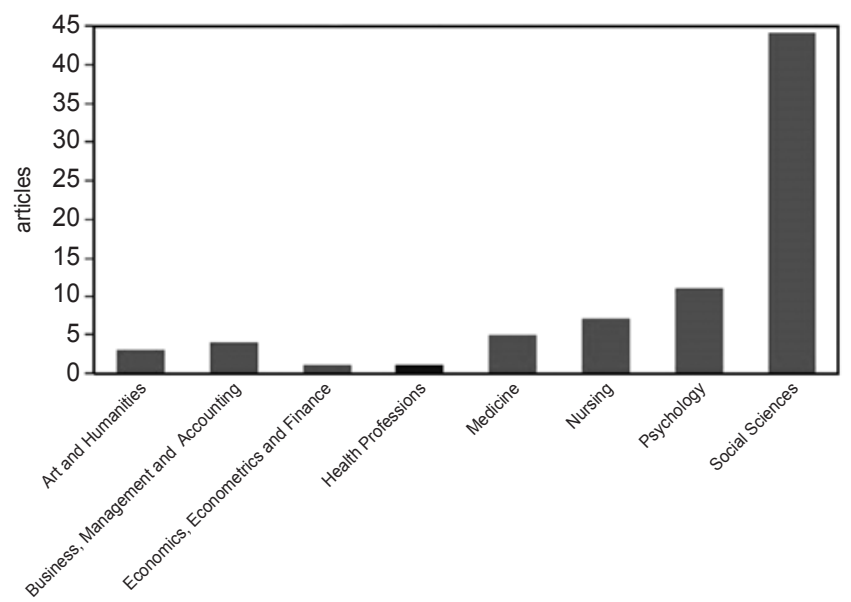

Figure 2. Distribution of articles published by disciplinary field.

This may be linked to the fact that feminist thought is aimed at developing a critical examination of society and culture and the degree in which gender power has had a significant dominance in the social sciences of which it is part. Feminist thought by its own profile, is capable of performing these analyzes, interpreting, and proposing alternative conceptions to promote a more humanistic integration, in equity and devoid of social discrimination. Although recently there have been approaches of this sort in natural, medical and experimental sciences which attempt to understand areas of these disciplines from a feminist perspective, this is not relevant when compared to what is seen in the social sciences.

The total of the articles is distributed in 40 different journals, and among those there are some that have two or more articles about that topic published within the same period: Women Studies International Forum, Sex Roles, Journal of Advanced Nursing, Gender Place \& Culture, and Counseling Psychologist.

\footnotetext{
2 The human development index (HDI) is a combined measure of life expectancy, literacy, education, quality of life that is useful to compare different countries. Measuring leves of life and the investment in new generations is done based upon a standard unit that provides information on the impact of economical policies over quality of life and its use allows to classify countries as developed, developing or underdeveloped. This human development paradigm in which the index was formulated was first proposed in 1990 by economists
} 
$\underline{\text { Table } 1}$

Articles organized by first author, country, number of coauthors, sex and citations.

\begin{tabular}{|c|c|c|c|c|c|c|}
\hline Year & First author & Country & $\begin{array}{c}\text { Authors } \\
\text { (fem/mas) }\end{array}$ & $\begin{array}{l}\text { Female } \\
\text { authors }\end{array}$ & $\begin{array}{l}\text { First female } \\
\text { author }\end{array}$ & Citation \\
\hline 1984 & Gould, Ketayun H. & USA & 1 & 1 & 1 & 0 \\
\hline 1987 & Bloch, Charlotte & Denmark & 1 & 1 & 1 & 1 \\
\hline 1989 & Aguilar, Delia D. & USA & 1 & 1 & 1 & 3 \\
\hline 1993 & Rutledge Shields, Vickie & USA & 2 & 2 & 1 & 16 \\
\hline 1993 & Fischer, Eileen M. & Canada & 3 & 3 & 1 & 136 \\
\hline 1996 & Thompson, Isabelle K. & USA & 1 & 1 & 1 & 3 \\
\hline 1996 & Twine, France W. & USA & 1 & 1 & 1 & 40 \\
\hline 1996 & Hathaway, James T. & USA & 1 & 0 & 0 & 0 \\
\hline 1998 & Buck, Lori & Canada & 3 & 2 & 1 & 5 \\
\hline 1998 & Henley, Nancy M. & USA & 5 & 3 & 1 & 67 \\
\hline 1998 & Burns, Linda & Australia & 1 & 1 & 1 & 0 \\
\hline 1999 & Sebrant, Ulla & Sweden & 1 & 1 & 1 & 12 \\
\hline 2000 & Yohei, Murata & Japan & 1 & 0 & 0 & 0 \\
\hline 2001 & Im, Eun Ok & USA & 1 & 1 & 1 & 9 \\
\hline 2001 & Wallace, Michelle & Australia & 1 & 1 & 1 & 1 \\
\hline 2001 & Schmied, Virginia A. & Australia & 2 & 2 & 1 & 14 \\
\hline 2002 & Peckover, Sue & England & 1 & 1 & 1 & 31 \\
\hline 2002 & Dempsey, Ken & Australia & 1 & 0 & 0 & 20 \\
\hline 2004 & Ditz, Toby L. & USA & 1 & 0 & 0 & 19 \\
\hline 2004 & Peter, Elizabeth H. & Canada & 3 & 3 & 1 & 37 \\
\hline 2004 & Laitinen, Irmeli & England & 2 & 2 & 1 & 5 \\
\hline 2004 & Oliveira, Dora Lucia & Brazil & 4 & 2 & 1 & 5 \\
\hline 2006 & Cross, Patricia A. & USA & 2 & 2 & 1 & 16 \\
\hline 2006 & Clayton, Ben & England & 2 & 1 & 0 & 9 \\
\hline 2006 & Robson, Elsbeth & Malawi & 1 & 1 & 1 & 1 \\
\hline 2006 & Wood, Mitchell J. & USA & 1 & 0 & 0 & 19 \\
\hline 2006 & Obando Salazar, Olga & Colombia & 1 & 1 & 1 & 1 \\
\hline 2007 & Few, April L. & USA & 1 & 1 & 1 & 13 \\
\hline 2007 & Herzog, Sergio & Israel & 1 & 0 & 0 & 4 \\
\hline 2007 & Da Silva, Susana M.V., & Brazil & 2 & 2 & 1 & 0 \\
\hline 2008 & Rocheleau, Dianne E. & USA & 1 & 1 & 1 & 25 \\
\hline 2008 & Jones, Lani V. & USA & 2 & 2 & 1 & 5 \\
\hline 2008 & Herzog, Sergio & Israel & 1 & 0 & 0 & 1 \\
\hline 2008 & Yick, Alice G. & USA & 2 & 2 & 1 & 5 \\
\hline 2008 & Mazur, Amy G. & USA & 1 & 1 & 1 & 1 \\
\hline 2009 & Bashevkin, Sylvia & Canada & 1 & 1 & 1 & 2 \\
\hline 2010 & Ferguson, Lucy & England & 1 & 1 & 1 & 5 \\
\hline 2010 & Kalviknes Bore, Inger L. & England & 1 & 1 & 1 & 0 \\
\hline 2010 & Hofbauer, Johanna & Austria & 1 & 1 & 1 & 0 \\
\hline 2010 & Ergün, Emek & USA & 1 & 1 & 1 & 3 \\
\hline 2010 & Plummer, Marilyn & Canada & 2 & 2 & 1 & 0 \\
\hline 2010 & Oberhauser, Ann M. & USA & 1 & 1 & 1 & 1 \\
\hline
\end{tabular}


Table 1 (continued):

Articles organized by first author, country, number of coauthors, sex and citations.

\begin{tabular}{lllcccc}
\hline Year & \multicolumn{1}{c}{ First author } & \multicolumn{1}{c}{ Country } & $\begin{array}{c}\text { Authors } \\
\text { (fem/mas) }\end{array}$ & $\begin{array}{c}\text { Female } \\
\text { authors }\end{array}$ & $\begin{array}{c}\text { First female } \\
\text { author }\end{array}$ & Citation \\
2010 & Motulsky, Sue L. & USA & 1 & 1 & 1 & 4 \\
2010 & Fardon, Jill & South Africa & 2 & 2 & 1 & 0 \\
2011 & Rose, Donald N. & Canada & 5 & 4 & 1 & 3 \\
2011 & Singh, Devendra, N. & USA & 2 & 1 & 0 & 3 \\
2011 & Holmberg, Tora & Sweden & 1 & 1 & 1 & 0 \\
2011 & Newmahr, Staci & USA & 1 & 1 & 1 & 0 \\
2012 & Shea, Jennifer M. & Canada & 2 & 2 & 1 & 1 \\
2012 & Selwyn, Neil & England & 1 & 0 & 0 & 1 \\
2012 & Marlow, Susan & England & 2 & 2 & 1 & 1 \\
2012 & Bilić, Bojan & England & 1 & 0 & 0 & 0 \\
2012 & Mínguez, Almudena M. & Spain & 1 & 1 & 1 & 0 \\
2013 & Falender, Carol A. & USA & 3 & 1 & 1 & 1 \\
\hline
\end{tabular}

As for the affiliation of the authors who produced SCOPUS articles on the subject during the period under study, they were distributed in 61 institutions, most with only one article with the exception of the University of Toronto (Canada) with four articles, and two from each of the following universities: Carleton, Ottawa (Canada), Sheffield (England), the Hebrew University of Jerusalem (Israel), the University of Albany, NY, and the University of California, at LA, these last two from USA.

\section{Analysis of the authors by sex, first author and citations}

Additionally, a detailed analysis of gender participation of the co-authors, of the total number of female and male authors and of the sex of the first author was made. These data are presented in Table 1 per article, recovering in all cases the name of each author. In that table the name of the first author is recorded, to document their sex as well as the country of the institution to which each author was attached or where he worked during the time the publication took place.

Interestingly, a total of 37 items, that is, $69 \%$ of the investigations had a single author and $79 \%$ of them were unique female authors. This fact is surprising given that for empirical studies it is often common to find multiple authors and in many cases at least in recent decades, the presence of collaborative networks is promoted both by some bibliometric indicators of scientific journals and by higher education and research institutions to ensure multiple inter-agency and international co-authorship. This is probably due to the fact that several of the studies analyzed corresponded rather to theoretical elaborations or scientific essays usually designed individually and less to extensive empirical studies that would demand collaborative work or networks.

The maximum number of authors in the articles analyzed during the period was five in that category and only two of the 54 articles studied were found. In 43 cases, that is, $80 \%$ of the articles, women were the first authors.

Cases of male first authors occurred for articles of Japanese origin (1), from Israel (2), from USA (4), Australia (1) and England (3), and of these, $82 \%$ were single- author articles. These two aspects of the distribution of authorship by gender illustrates something that is seen in other academic spaces in this subject area, where the central interest is shown by women who appear more frequently studying, researching and publishing on issues with a feminist perspective. This is the case of the present study, when more women are seen as the leading authors for this kind of articles.

The few male authors that had mentioned the feminist perspective basically worked alone and / or have devoted to masculinity issues, or to subjects of male homosexuality.

Table 1 also shows the cumulative count of citations per article, ranging from zero to 136 for the group of articles analyzed. That count was previously purged of self-citations. The top five post for citations were occupied in order by Canada, USA and England and the h-index of the total sample was 13 , that is, 13 articles were cited at least 13 times.

The Canadian article written by three women, Eileen Fischer, Rebecca Reuben and Lorraine Dyke (1993) on a theoretical review of the relationship between sex, gender and being an entrepreneur had been the most cited during the period (136). The second place went to a U.S. article 
with 67 citations, written by Nancy Henley, Karen Meng, Delores O'Brien, William McCarthy and Robert Sockloskie (1998) on the validation of a scale that assessed the diversity of feminist attitudes. The next place corresponded to a study by France Winddance Twine from the US, with a total of 40 citations that addressed the issue of ethnicity and the construction of white identity in suburban American communities. The fourth place was taken by the Canadian paper of Elizabeth Peter, Amy Macfarlane and Linda Lee O'Brien-Pallas (2004), with 37 citations, which addressed the moral habitability of the work environment in which nurses operate. The fifth place went to a British article by Sue Peckover (2002) with 31 citations, for a study of professional practices of health inspections for abused mothers.

The cases of zero citations are mainly concentrated for papers published in recent years, starting in 2010, as expected for the shortest period of exposure in comparison with other published articles, the exception to this trend occurred for two American papers, one published by Ketayun Gould (1984), about the double risk of African American women on birth control, which incidentally was the first paper published on the subject of feminist perspective in SCOPUS and the second case for a paper by James Hathaway (1996) on the use of public bars by women in Nigeria. That lack of popularity was also shared by a Japanese article of Yohei Murata (2000) on the alienation experienced by single men in adulthood due to changes in gender roles that society has undergone. The same happened to a Brazilian paper by Susana da Silva (2007) on the geography of gender in Latin America, which examines the cases of Argentina and Brazil.

\section{Thematic analysis}

Regarding subjects dealt with, it can be said that the main thrust of the group of studies with feminist perspective came from the sociological field, followed by the psychological area, although it is worth remembering that by definition gender research has a highly interdisciplinary nature.

A consolidate of disciplinary approaches, themes and a summary of the conclusions offered by the sample of studies analyzed, sorted chronologically is presented in Table 2. The large majority of these studies adopted a explicit postmodern feminist position, regardless of their main disciplinary focus. Table 2 (Annex 1), like Table 1, include the first name of the main author, to make visible their sex ; in case of doubt with unfamiliar names, these data are available for coauthors in Table 1, or in particular for each author in Figure 4, which presents this information for all individual authors involved.

The range of topics discussed during three decades reflects aspects of sociology of science that go beyond the purpose of this analysis, however it can be said that there are few studies that have addressed the impact of a feminist theory on social change in favor of gender equity. For example, in the sample of the SCOPUS articles analyzed only two of them, that is $4 \%$, focused on the issue of the influence that feminist theory has had in changing public policy (Ferguson, 2010; Mazur, 2008) while 4 papers (8\%) reported situations of inequality in the exercise of citizens' rights by reason of gender (Buck, Gallant \& Nossal, 1998; da Silva \& Lan, 2007; Minguez, 2012), or the use of "politically correct" feminist language in political campaigns (Bashevkin, 2009).

Education is another key aspect that can evaluate the influence of feminist theory in contemporary society. This field has not been sufficiently studied in the articles of the sample analyzed, as only three studies, $6 \%$ of them, treated the subject with a rather tangential approach. One of the articles dealt with the educational theme focused on marginalized young women discriminated against because of their race (Obando-Salazar, 2006), one addressed the issue of the influence of digital technology on formal and informal education (Selwyn, 2012) and another dealt with teaching communication skills (Thompson, 1996). Based on these considerations it is concluded that treatment of subjects to analyze and propose social changes in the sample of articles from a feminist perspective has been rather meager, possibly due to the socio-economic characteristics of the countries represented in the sample.

In addition to the above cases, the studies included issues of masculinity, sexuality, differential impact of the media over men and women, especially television and issues of racism.

Three studies of the sample $(6 \%)$ were devoted to the topic of masculinity: Clayton and Humberstone (2006), Ditz (2004) and Yohei (2000), gathering 9, 19 and 0 citations respectively.

Three other items ( $6 \%$ of the total) addressed the analysis of sexual practices from a feminist approach: Cross and Matheson (2006), Oliveira, Meyer, Santos and Wilhelms (2004) and Wood (2006), the latter focusing on male homosexual practices.

Two studies (4\%) analyzed television messages in relation to gender from a feminist perspective (Kalviknes-Bore, 2010; Oliveira, Meyer, Santos \& Wilhelms , 2004).

Finally the issue of racism that intersects with gender inequality was approached by four studies ( $8 \%$ of the total), with papers by Few (2007), Gould (1984), Obando -Salazar (2006) and Twine (1996).

\section{Analysis by collaborative networks}

The analysis of collaborative networks of research articles with feminist perspective for the period between 1960 and 2013 are shown in Figures 3 and 4. 
In both figures collaborative networks between authors are represented using lines and nodes. In Figure 3 the first authors of each paper are represented by a triangle, whose size varies in direct proportion to the number of citations and / or frequency of articles written during the period. To identify the first authors, their last name is used, followed by the year of publication of the paper, underneath the country and the number in brackets represents citations made by other SCOPUS authors to each paper. The names of the coauthors identify the other nodes of each network. For solo authors only a triangle appears without any binding line.

Figure 3 is organized by country, so that in the left vertical sections are grouped in descending chronological order, the 22 articles of US origin issued during the period from 1984 to 2013. As in the case of Table 1, the nationality of the papers is determined by the institution of affiliation of the first author.

In this subgroup only two cases were written with more than two authors, an article of 1998 and one of 2013, five articles were produced in dyads, and the solitary authorship predominated. The US article with more quotes totaled 67 during the period (Henley, Meng, O'Brien, McCarthy $\&$ Sockloskie, 1998). Only 9 of the 22 items reached individual citation above 9, which is the group h- index for the American papers adopting a feminist perspective.

To the right of the first group, the networks of authors that had published from a feminist perspective from institutions of Canadian origin were located. As in the previous case all items from this source were arranged vertically according to their date of publication, in descending order, in this case from 1993 to 2012. For this subgroup, the four items, that is, 57\% of the networks nodes had a number equal to or greater than 3 . The area of the networks in the figure also keeps a relationship with the number of citations per article. The article by Fischer, Reuber and Dyke (1993) was the one with the most impact of the subgroup and also from the total sample of 54 articles with 136 citations. The $h$ index for the Canadian subgroup was 3.5.

The largest oval group on the right side of Figure 3, represents the networks of English authors who published studies from a feminist perspective in the period analyzed. Of these, only 3 were produced in dyads and the rest were written by a single author. The arrangement is also presented in descending chronological order, in this case for the period covering 2002 through 2012. In this subgroup, the article by Peckover (2002) got the largest number of citations, with a total of 3 . The h-index subgroup for English papers was 4, that is, 4 articles had at least 4 citations.

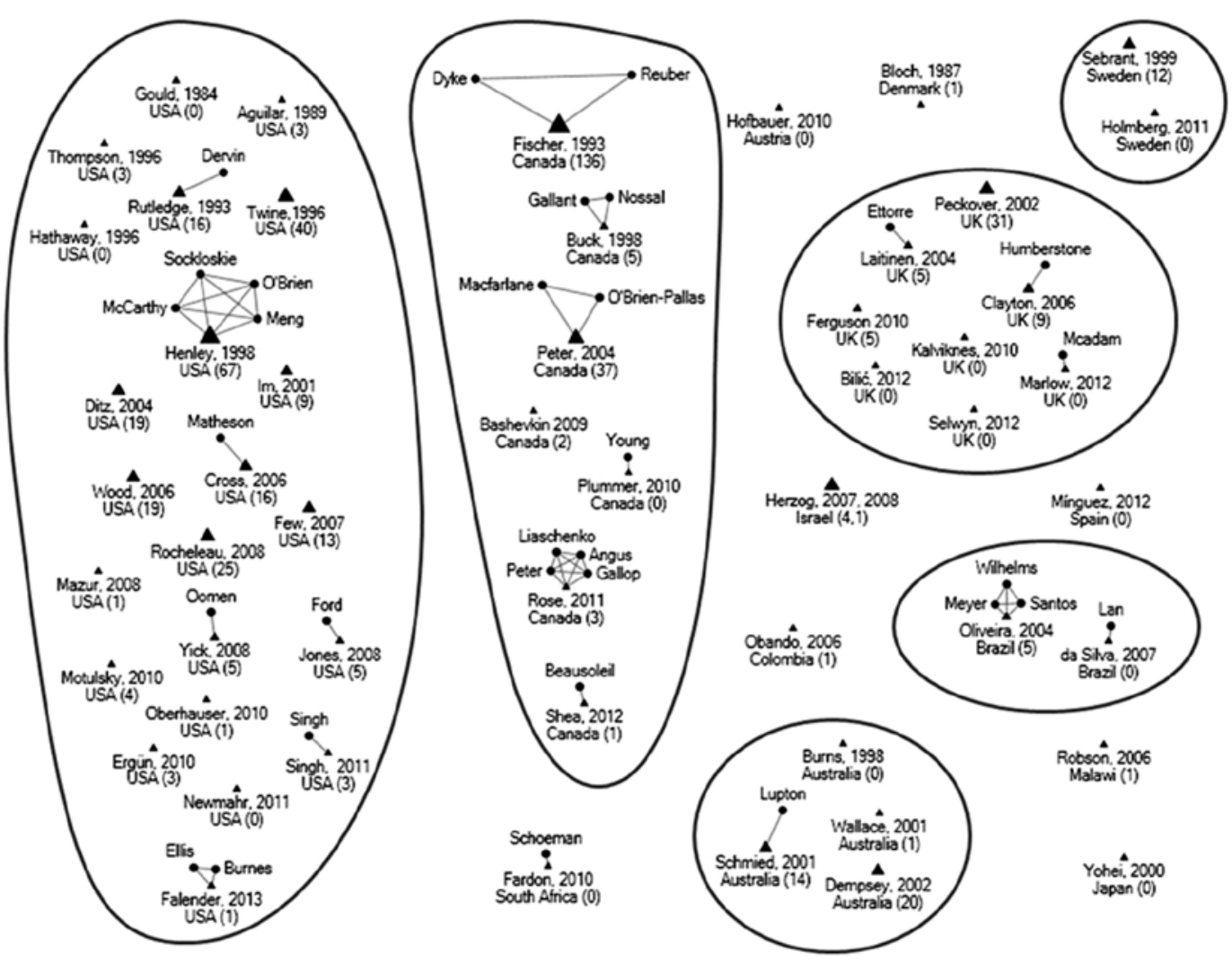

Figure 3. Networks of scientific production of research with feminist perspective, by year, country of origin of the first author and number of citations. Note: figure created by the software NodEXL Network graphs, version 1.0.1.238. 
The following subgroups identified by the three remaining balloons, corresponded following clockwise from the top right corner to Sweden, Brazil and Australia, with maximum 12 citations, 5 references and 20, respectively. Of these three subgroups, the only occurrence of a network with more than 3 nodes was for an article of Brazilian origin in 2004.

Eight additional countries recorded publications with a feminist perspective for the period covered by this analysis , among which are: Denmark, Austria, Spain, Israel, the latter with a double share of the same author, Colombia, Malawi, Japan and South Africa, with all but the last articles with a single author.

Figure 4 was designed with the same logic used for the previous figure, with a change in notation. This figure shows the sex of the authors by means of the shape of the nodes. The circles represent female authors while empty diamonds stand for male authors. For readability the same distribution and signaling format was used as in figure 3 .

Differentiation of individual authors offered in this figure, makes possible to analyze in detail the contribution and distribution of researchers within collaborative networks as well as by geographic area, while at the same time, year of publication and citations for each article are available at a glance.

As shown in Figure 3, for the US subgroup, in all cases with one exception, women occupied the first place in the authorship of studies with more than one node. The exception was for the case of Singh and Singh (2011). From a total of 22 US publications with 33 authors, 8 of them were males, of which 3 of them wrote papers alone.

The publication by a single author was preponderant in the set of articles analyzed with a feminist perspective, as $61.1 \%$ of the writings of both sexes were recorded in this mode and $24.2 \%$ of them came from male authors. Particularly for articles with a theoretical or conceptual component is more common to find them written by a single author, due to the advantages that implies to proceed in this fashion, while complex empirical research, on the other hand, often requires the concert of a group of authors. For the studies reported here a mix of empirical- conceptual elements was observed in which authorship by a single person predominated. This trend may also be due to the relative youth of this interdisciplinary area.

Following the analysis by geographic region and sex, for the Canadian subgroup with 7 articles, there were only two

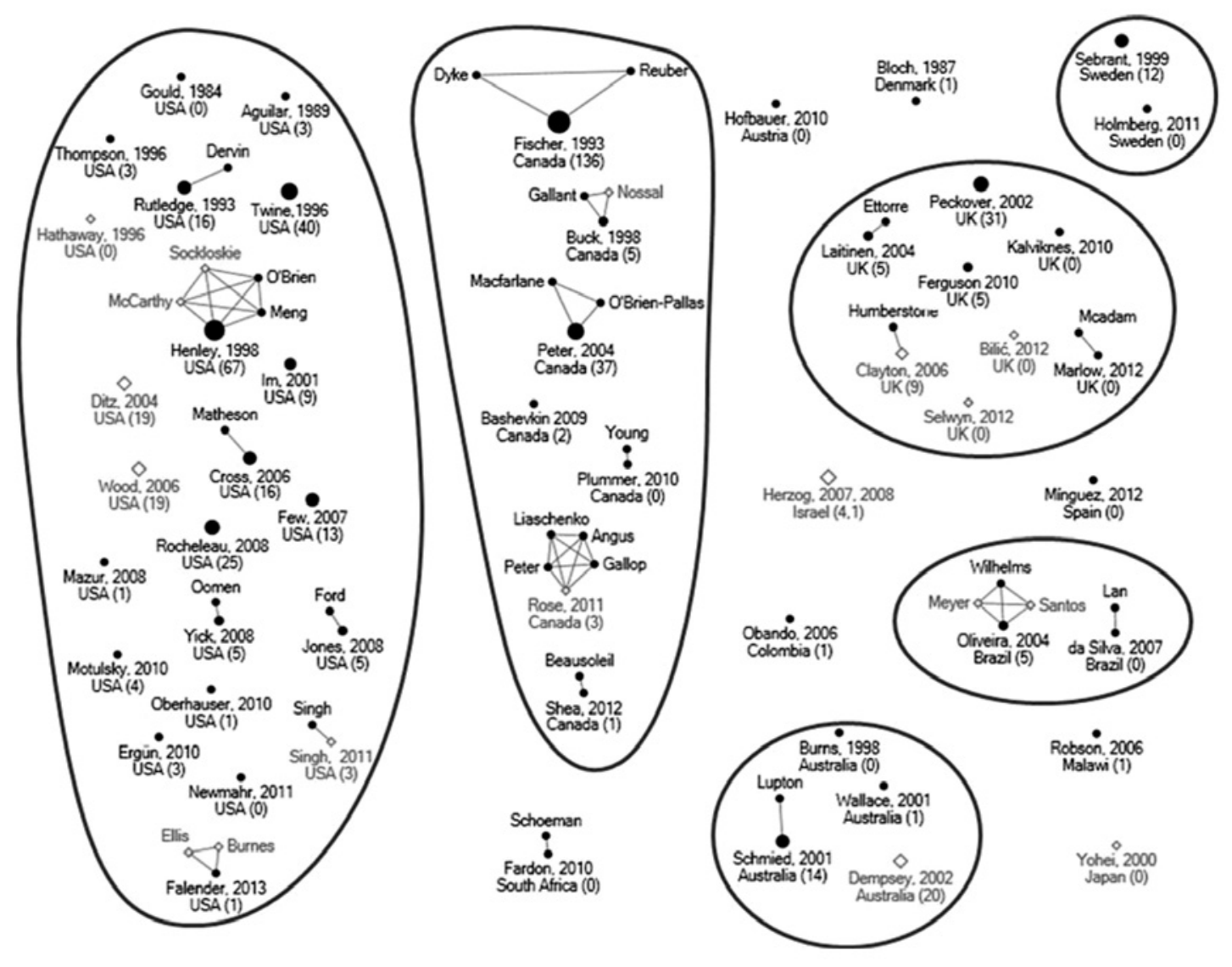

Figure 4. Network of scientific production of research with feminist perspective by sex of the authors.

Note: figure created by the software NodEXL Network graphs, version 1.0.1.238. 
male authors of a total of 19 , including one researcher leader of a group of four female researchers (Rose, Peter, Gallop, Angus \& Liaschenko, 2011) in a study of forensic nursing, and another one participating as a third author in a study of state policies in Iraq (Buck, Gallant \& Nossal, 1998).

With respect to the subgroup of 8 English papers, there were 11 authors, three were males and only one of them appeared as the first author of a publication with a feminist perspective in a mixed dyad, that is, with a female author (Clayton \& Humberstone, 2006).

In other national subgroups, as in the case of Brazil, no males led articles on the feminist perspective, but two male researchers participated as co-authors in a study about feminism and media (Oliveira, Meyer, Santos \& Wilhelms , 2004). On the other hand, in the case of Australia, a male author (Dempsey, 2002) published a single author study on differential gender benefit as a result of marriage, receiving 20 citations, the top popularity for that national subgroup.

Additionally, a Japanese male author (Yohei, 2000) and a man from Israel (Herzog , 2007, 2008 ) published studies by themselves with a feminist perspective.

The three studies on masculinity had a first male author (Clayton \& Humberstone , 2006; Ditz , 2004; Yohei , 2000) and corresponded to studies of English, American and Japanese origin respectively.

\section{DISCUSSION}

A review of the literature published in indexed journals in the bibliometric database SCOPUS from four terms: "study", " empirical ", "perspective " and " feminist " yielded a relatively small corpus of research, consisting of 54 writings inspired by the feminist theoretical stance .

The results would probably have been different if the search words used had been other terms, such as "gender studies". However, as noted by Bosch and Ferrer "gender studies are feminist studies" (2002, p. 237). One of the main contributions of the conceptual category "gender", born within the feminist theory is to emphasize the relationship between masculinity and femininity as a result of a process of cultural learning and socialization (Bosch, 2001). Future scientometric studies might be able to respond the empirical question whether the articles on gender studies differ or not from articles that expressly adopt a feminist approach.

This research, based upon the review of the past three decades from the first publication of studies on the subject, shows that most of these publications were the product of the reflection of a single author, that most of the authors dealing with the feminist perspective have been women, mainly from the social sciences, most of them from the US and the vast majority of English-speaking countries.
While it was decided that one of the defining terms that the papers referred to empirical issues, some of the essays were devoted to theoretical considerations within various fields of knowledge. This finding strengthens the notion that feminist research has a strong multidisciplinary, interdisciplinary and trans- disciplinary theoretical accent.

It is important to note that one of the characteristics of this field of knowledge in Latin American countries, shared with other areas of the social sciences, is that in practice, most of the knowledge generated is disseminated through books, instead of doing it by means of articles published in indexed scientific journals. The academic pressures to which authors are subjected by their institutions, as well as by the Councils of Science and Technology regulating the production of national scientific knowledge, suggests that the trend is precisely to increase the presence of knowledge production of these research groups in national and international indexed journals. The Councils for Science and Technology reward scientists who publish in certain journals and in some cases they have adopted criteria that some authors consider erroneous and misinformed, when employing in an unfortunate way some bibliometric indices such as the impact factor (Aleixandre-Benavent, ValderramaZurián \& González-Alcaide, 2007; Falagas , Kouranos , Arencibia-Jorge \& Karageorgopoulos , 2008) to regulate their policies developed for assessing researchers/authors.

Additionally, the picture presented by the different topics addressed by this study leads to consider the desirability and need for more international research on two themes. In the first place, to review the way in which the change in advanced societies in favor of the enjoyment of equal rights for women and men was produced and consolidated, so the less advanced societies where gender inequalities are invisible could learn from successful cases. And in second place, the need for studies that analyze the impact of the feminist point of view on education, health, labor and public policy in order to show the government and private decision- makers, the benefits that would bring the inclusion of this perspective in the design of practices in those sectors.

Making a comparative analysis of three bibliometric databases, covering Latin American journals, REDALYC, SCIELO and SCOPUS, the latter is considered the one with more stringent criteria for entry and permanence (Miguel, 2011), which guarantees a minimum level of quality for all the papers of its collection. Additionally, SCOPUS has the highest volume of articles from the region, in a ratio of 3:1 compared to SCIELO, and 6:1 ratio compared to REDALYC because much of Latin American scientific production is published in foreign journals (Miguel, 2011).

Despite this, recent data covering Latin American scientific journals by the SCOPUS database showed that 
it was only of $1.01 \%$, which does not mean that no scientific knowledge is produced in the region, but that despite the existence of numerous scientific journals in different fields of knowledge in Latin America, the fact is that these publications are not part of the mainstream and the vast majority are not yet included in the international indexes specialized for different reasons (Cetto, Alonso- Gamboa \& Cordoba notes -González, 2010), among which it was found that editors make mistakes such as delays in their release schedules, heterogeneous quality of writing, inbreeding, oversights and omissions related to the format that should be written on one side and on the other, the low citation of those articles, because the authors from developed countries generally do not pay attention to the topics covered by Latin American scientists and mainly Latin American authors themselves cite authors only from the first world and rarely cite their regional colleagues, because they believe they do not represent prestigious sources of knowledge that they could use.

One of the current challenges for the Latin American scholars investigating the impact of gender inequality in various fields of human endeavor is precisely to increase the visibility of their field through increasing their participation in journals indexed in prestigious international databases.

Besides the challenge already mentioned at the individual level, in parallel, an unavoidable task for the scientific institutions of the region will be the creation and strategic support for high quality Latin American journals to cover the requirements that might open the doors of international indexing, as well as the use of appropriate techniques and electronic resources, the use of high-quality metadata, the increment of properly trained editors (Cetto et al, 2010) and ideally the open access distribution of knowledge (Babini , 2011) so that gradually a well-grounded science accessible for all, designed and disseminated in Spanish and simultaneously translated into the major languages of science could be produced in the region.

\section{REFERENCES}

References preceded by an asterisk are the ones in which the scientometric analysis was based upon.

Adán, C. (2006) Feminismo y conocimiento.[Feminism \& knowledge]. Galicia, Spain: Ediciones Espiral Maior.

*Aguilar, D. D. (1989). The social construction of the Filipino woman. International Journal of Intercultural Relations, 13 (4), 527-551.

Aleixandre-Benavent, R., Valderrama-Zurián, J. C., \& González-Alcaide, G. (2007). El factor de impacto de las revistas científicas: limitaciones e indicadores alternativos.[The impact factor of scientific journals: limitations and alternative indicators]. El profesional de la información, 16, 1, 4-11.
Babini, D. (2011). Acceso abierto a la producción científica de América Latina y el Caribe. Identificación de principales instituciones para estrategias de integración regional. [Open access to scientific production in Latin America and the Caribean. Identification of the main institutions for strategies of regional integration]. Revista Iberoamericana de Ciencia, Tecnología y Sociedad CTS, 6, 17, 1-24. Consultado Septiembre 14, 2013, disponible en: http://hdl.handle. net/10760/15574

*Bashevkin, S. (2009). Party talk: Assessing the feminist rhetoric of women leadership candidates in Canada. Canadian Journal of Political Science, 42 (2), 345-362, available via: http://dx.doi.org/10.1017/S0008423909090325

*Bilić, B. (2012). Not in our name: Collective identity of the Serbian Women in Black. Nationalities Papers, 40 (4), 607-623, available via: http://dx.doi.org/10.1080/00905992.2012.692510

*Bloch, C. (1987). Everyday life, sensuality, and body culture. Women's Studies International Forum, 10 (4), 433-442.

Bosch, E. (2001). Nuevas estrategias en las relaciones hombremujer, [New strategies in men-women relationships], Papeles de Cuestiones Internacionales, 73, 83-90.

Bosch, E., \& Ferrer, V. A. (2002). La voz de las invisibles. Las víctimas de un mal amor que mata. [The voice of the invisible women. The victims of a tragic love that kills]. Madrid: Cátedra.

*Buck, L., Gallant, N., \& Nossal, K. R. (1998). Sanctions as a gendered instrument of statecraft: The case of Iraq. Review of International Studies, 24 (1), 69-84.

*Burns, L. (1998). Fantasy, Memory and Reality: Psychoanalytic and Legal Perspectives on Rape. Feminism and Psychology, 8 (1), 7-23.

Cetto, A. M., Alonso-Gamboa, J. O., \& Córdoba-González, S. (2010). Ibero-American systems for the dissemination of scholarly journals: a contribution to public knowledge worldwide. Scholarly and Research Communication, 1(1): 010104, 16 pp. Retrieved September 14, 2013, from: http:// www.src-online.ca/index.php/src/article/viewFile/17/31

*Clayton, B., \& Humberstone, B. (2006). Men's talk: A (pro) feminist analysis of male university football players' discourse. International Review for the Sociology of Sport, 41 (3-4), 295-316, available via: http://dx.doi. org/10.1177/1012690207078380

*Cross, P. A., \& Matheson, K. (2006). Understanding sadomasochism: An empirical examination of four perspectives. Journal of Homosexuality, 50 (2-3), 133-166, available via: http://dx.doi.org/10.1300/J082v50n02 07

*Da Silva, S. M. V., \& Lan, D. (2007). Studies on geography and gender in Latin America. A state of the art through the cases of Brazil and Argentina. Documents d'Analisi Geografica, (49), 99-118.

De Moya-Anegon, F., Chinchilla-Rodriguez, Z., Vargas-Quesada, B., Corera-Alvarez, E., Munoz-Fernandez, F. J., GonzalezMolina, A., \& Herrero-Solana, V. (2007). Coverage analysis of Scopus: a journal metric approach. Scientometrics ,73, 53-78, available via: http://dx.doi.org/10.1007/s11192-007-1681-4

*Dempsey, K. (2002). Who gets the best deal from marriage: Women or men? Journal of Sociology, 38 (2), 91-110. 
*Ditz, T. L. (2004). The new men's history and the peculiar absence of gendered power: Some remedies from early American gender history. Gender and History, 16 (1), 1-35, available via: http://dx.doi.org/10.1111/j.0953-5233.2004.324_1.x

*Ergun, E. (2010). Bridging across feminist translation and sociolinguistics. Linguistics and Language Compass, 4 (5), 307-318, available via: http://dx.doi.org/10.1111/j.1749818X.2010.00208.X

Falagas, M. E., Kouranos, V. D., Arencibia-Jorge, R., \& Karageorgopoulos, D. E. (2008). Comparison of SCImago journal rank indicator with journal impact factor. The FASEB Journal, 22, 2623-2628.

*Falender, C. A., Burnes, T. R., \& Ellis, M. V. (2013). Multicultural clinical supervision and benchmarks: Empirical support informing practice and supervisor training. Counseling Psychologist, 41 (1), 8-27, available via: http://dx.doi. org/10.1177/0011000012438417

*Fardon, J., \& Schoeman, S. (2010). A feminist post-structuralist analysis of an exemplar South African school history text. South African Journal of Education, 30 (2), 307-323.

*Ferguson, L. (2010). Interrogating 'gender' in development policy and practice. International Feminist Journal of Politics, 12 (1), 3-24, available via: http://dx.doi. org/10.1080/14616740903429080

*Few, A. L. (2007). Integrating black consciousness and critical race feminism into family studies research. Journal of Family Issues, 28 (4), 452-473, available via: http://dx.doi. org/10.1177/0192513X06297330

*Fischer, E. M., Reuber, A. R., \& Dyke, L. S. (1993). A theoretical overview and extension of research on sex, gender, and entrepreneurship Journal of Business Venturing, 8 (2), 151-168.

*Gould, K. H. (1984). Black women in double jeopardy: a perspective on birth control. Health \& social work, 9 (2), 96-105.

*Hathaway, J. T. (1996). Women and the public drinking place: A case study of Ado-Ekiti, Nigeria. Singapore Journal of Tropical Geography, 17 (2), 132-149.

*Henley, N. M., Meng, K., O’Brien, D., McCarthy, W. J., \& Sockloskie, R. J. (1998). Developing a scale to measure the diversity of feminist attitudes. Psychology of Women Quarterly, 22 (3), 317-348.

*Herzog, S. (2008). The lenient social and legal response to trafficking in women: An empirical analysis of public perceptions in Israel. Journal of Contemporary Criminal Justice, 24 (3), 314-333, available via: http://dx.doi. org $/ 10.1177 / 1043986208318228$

*Herzog, S. (2007). Public perceptions of sexual harassment: An empirical analysis in Israel from consensus and feminist theoretical perspectives. Sex Roles, 57 (7-8), 579-592, available via: http://dx.doi.org/10.1007/s11199-007-9220-6

*Hofbauer, J. (2010). Social homogeneity and cultural hegemony: Exclusion and organization from a Bourdieusian perspective [Soziale homogenität und kulturelle hegemonie. Ausschließung und organisation aus Bourdieuscher perspektive]. Feministische Studien, 28 (1), 25-39.

*Holmberg, T. (2011). Mortal love: Care practices in animal experimentation. Feminist Theory, 12 (2), 147-163, available via: http://dx.doi.org/10.1177/1464700111404206
Informe sobre Desarrollo Humano (2013) El ascenso del Sur: Progreso humano en un mundo diverso. [The rising of the South: Human progress in a diverse world]. Publicado por PNUD, Nueva York, USA. Consultado: Septiembre 1ero. 2013. Disponible en http://www.undp.org/content/dam/ undp/library/corporate/HDR/2013GlobalHDR/Spanish/ HDR2013\%20Report\%20Spanish.pdf

*Im, E.-O. (2001). Nursing research on physical activity: A feminist critique. International Journal of Nursing Studies, 38 (2), 185-194, available via: http://dx.doi.org/10.1016/ S0020-7489 (00)00040-7

*Jones, L. V., \& Ford, B. (2008). Depression in African American women: Application of a psychosocial competence practice framework. Affilia - Journal of Women and Social Work, 23 (2), 134-143, available via: http://dx.doi. org/10.1177/0886109908314324

*Kalviknes Bore, I. L. (2010). (Un) funny women: TV comedy audiences and the gendering of humour. European Journal of Cultural Studies, 13 (2), 139-154, available via: http:// dx.doi.org/10.1177/1367549409352272

*Laitinen, I., \& Ettorre, E. (2004). The women and depression project: Feminist action research and guided self-help groups emerging from the Finnish women's movement. Women's Studies International Forum, 27 (3), 203-221, available via: http://dx.doi.org/10.1016/j.wsif.2004.04.002

*Marlow, S., \& Mcadam, M. (2012). Analyzing the influence of gender upon high-technology venturing within the context of business incubation entrepreneurship. Theory and Practice, 36 (4), 655-676, available via: http://dx.doi. org/10.1111/j.1540-6520.2010.00431.x

*Mazur, A. G. (2009). Feminist movements and the elaboration of policies in a comparative perspective: Towards a gendered approach of democracy [Les mouvements féministes et l'élaboration des politiques dans une perspective comparative. Vers une approche genrée de la démocratie]. Revue Francaise de Science Politique, 59 (2), 325-351.

Miguel, S. (2011). Revistas y producción científica de América Latina y el Caribe: su visibilidad en SciELO, REDALyC y SCOPUS. [Journals and scientific production in Latin America and the Caribbean: Its visibility in SciELO, REDALYC and SCOPUS]. Revista Interamericana de Bibliotecología, $34,2,187-199$.

*Mínguez, A. M. (2012). Gender, family and care provision in developing countries: Towards gender equality. Progress in Development Studies, 12 (4), 275-300, available via: http:// dx.doi.org/10.1177/146499341201200402

*Motulsky, S. L. (2010). Relational processes in career transition: Extending theory, research, and practice. Counseling Psychologist, 38 (8), 1078-1114, available via: http:// dx.doi.org/ 10.1177/0011000010376415

*Newmahr, S. (2011). Chaos, order, and collaboration: Toward a feminist conceptualization of edgework. Journal of Contemporary Ethnography, 40 (6), 678-708, available via: http://dx.doi.org/10.1177/0891241611425177

*Obando Salazar, O. L. (2006). An antiracist research and intervention study: A gender perspective. Interamerican Journal of Psychology, 40 (3), 313-332. 
*Oberhauser, A. M. (2010). (Re) Scaling gender and globalization: Livelihood strategies in Accra, Ghana. ACME, 9 (2), 221-244.

*Oliveira, D. L., Meyer, D. E., Santos, L. H., \& Wilhelms, D. M. (2004). Safe sex negotiation on TV: gender discourses among female community health workers under the Family Health Program in Porto Alegre, Rio Grande do Sul, Brazil [A negociação do sexo seguro na TV: discursos de gênero nas falas de agentes comunitárias de saúde do Programa Saúde da Família de Porto Alegre, Rio Grande do Sul, Brazil.] Cadernos de saude publica / Ministerio da Saude, Fundacao Oswaldo Cruz, Escola Nacional de Saude Publica, 20 (5), 1309-1318.

*Peckover, S. (2002). Supporting and policing mothers: An analysis of the disciplinary practices of health visiting. Journal of Advanced Nursing, 38 (4), 369-377, available via: http://dx.doi.org/10.1046/j.1365-2648.2002.02197.x

*Peter, E. H., Macfarlane, A. V., \& O'Brien-Pallas, L. L. (2004). Analysis of the moral habitability of the nursing work environment. Journal of Advanced Nursing, 47 (4), 356-364, available via: http://dx.doi.org/10.1111/j.13652648.2004.03113_1.x

*Plummer, M., \& Young, L. E. (2010). Grounded theory and feminist inquiry: Revitalizing links to the past. Western Journal of Nursing Research, 32 (3), 305-321, available via: http://dx.doi.org/10.1177/0193945909351298

PNUD (2013) Sitio web de PNUD, Nueva York, USA. Consultado: Septiembre 1ero. 2013. Disponible en: http://hdr. undp.org/es/desarrollohumano/origenes/

*Robson, E. (2006). The 'kitchen' as women's space in rural Hausaland, Northern Nigeria. Gender, Place and Culture, 13 (6), 669-676, available via: http://dx.doi. org/10.1080/09663690601019869

*Rocheleau, D. E. (2008). Political ecology in the key of policy: From chains of explanation to webs of relation. Geoforum, 39 (2), 716-727, available via: http://dx.doi.org/10.1016/j. geoforum.2007.02.005

*Rose, D. N., Peter, E., Gallop, R., Angus, J. E., \& Liaschenko, J. (2011). Respect in forensic psychiatric nursepatient relationships: A practical compromise. Journal of Forensic Nursing, 7 (1), 3-16, available via: http://dx.doi. org/10.1111/j.1939-3938.2010.01090.x

*Rutledge Shields, V., \& Dervin, B. (1993). Sense-making in feminist social science research. A call to enlarge the methodological options of feminist studies. Women's Studies International Forum, 16 (1), 65-81.

*Schmied, V., \& Lupton, D. (2001). The externality of the inside: Body images of pregnancy. Nursing Inquiry, 8 (1),
32-40, available via: http://dx.doi.org/10.1046/j.14401800.2001.00088.x

Sebrant, U. (1999). Being female in a health care hierarchy - On the social construction of gender and leader identity in a work organization having a predominance of women. Scandinavian Journal of Caring Sciences, 13 (3), 153-158, available via: http://dx.doi.org/10.1080/02839319950162507

*Selwyn, N. (2012). Making sense of young people, education and digital technology: The role of sociological theory. Oxford Review of Education, 38 (1), 81-96, available via: http://dx.doi.org/10.1080/03054985.2011.577949

*Shea, J. M., \& Beausoleil, N. (2012). Breaking down 'healthism': barriers to health and fitness as identified by immigrant youth in St. John's, NL, Canada. Sport, Education and Society, 17 (1), 97-112, available via: http://dx.doi. org/10.1080/13573322.2011.607914

*Singh, D., \& Singh, D. (2011). Shape and Significance of Feminine Beauty: An Evolutionary Perspective. Sex Roles, 64 (9), 723-731, available via: http://dx.doi.org/10.1007/ s11199-011-9938-z

*Thompson, I. (1996). Competence and critique in technical communication: A qualitative content analysis of journal articles. Journal of Business and Technical Communication, $10(1), 48-80$.

*Twine, F. W. (1996). Brown skinned white girls: Class, culture and the construction of white identity in suburban communities. Gender, Place and Culture, 3 (2), 205-224.

*Wallace, M. (2001). Women and workplace training: Power relations positioning "The other". Women's Studies International Forum, 24 (3-4), 433-444, available via: http:// dx.doi.org/10.1016/S0277-5395(01)00169-8

*Wood, M. J. (2006). The gay male gaze: Body image disturbance and gender oppression among gay men. Journal of Gay and Lesbian Social Services, 17 (2), 43-62, available via: $\mathrm{http}: / / \mathrm{dx}$. doi.org/10.1300/J041v17n02_03

*Yick, A. G., \& Oomen-Early, J. (2008). A 16-year examination of domestic violence among Asians and Asian Americans in the empirical knowledge base: A content analysis. Journal of Interpersonal Violence, 23 (8), 1075-1094, available via: http://dx.doi.org/10.1177/0886260507313973

*Yohei, M. (2000). The places where middle-aged single men feel alienated. Human Geography, 52 (6), 1-19.

Zitt, M., \& Bassecoulard, E. (2008). Challenges for scientometric indicators: data demining, knowledge-flow measurements and diversity issues. Ethics in Science and Environmental Politics, 8, 49-60, available via: http://dx.doi. org/10.3354/esep00092 


\section{ANNEX 1}

Table 2

Focus, themes, and results from analyzed empirical articles with feminist perspective.

\begin{tabular}{|c|c|c|c|}
\hline First author (year) & Focus & Central theme & Conclusions \\
\hline Gould, Ketayun H. (1984) & Health & Birth control. & $\begin{array}{l}\text { Afro American women suffer a double } \\
\text { disadvantage. }\end{array}$ \\
\hline Bloch, Charlotte (1987) & Sociological & Two kinds of sensuality & $\begin{array}{l}\text { There are contradictions between feminist and } \\
\text { sportive vision of the body culture. }\end{array}$ \\
\hline Aguilar, Delia D. (1989) & Sociological & Subordinated status of women. & $\begin{array}{l}\text { Non feminist analysis of Filipino women in their } \\
\text { public and private functions is criticized. }\end{array}$ \\
\hline $\begin{array}{l}\text { Rutledge Shields, Vickie, et al. } \\
\text { (1993) }\end{array}$ & Sociological & $\begin{array}{l}\text { To widen up methodological } \\
\text { options of feminist studies. }\end{array}$ & $\begin{array}{l}\text { Criticism to the collaborative participation and } \\
\text { the overemphasis on intersubjectivity as the only } \\
\text { model. }\end{array}$ \\
\hline Fischer, Eileen M., et al. (1993) & Sociological & $\begin{array}{l}\text { On gender differences for } \\
\text { conducting business. }\end{array}$ & $\begin{array}{l}\text { Being a woman or a man is not an advantage or a } \\
\text { hindrance in the business world. }\end{array}$ \\
\hline Thompson, Isabelle K. (1996) & Pedagogic & $\begin{array}{l}\text { Pedagogic technical } \\
\text { communication at bachelors' } \\
\text { level. }\end{array}$ & $\begin{array}{l}\text { Comparison of } 4 \text { perspectives for analysis of } \\
\text { educational goals and social criticism of teaching } \\
\text { of communicative competences. }\end{array}$ \\
\hline Twine, France W. (1996) & Sociological & $\begin{array}{l}\text { Construction of white identity in } \\
\text { the suburbs. }\end{array}$ & $\begin{array}{l}\text { Underlines the central role of material privileges } \\
\text { of medium class in the social construction of } \\
\text { racial "white" identity. }\end{array}$ \\
\hline Hathaway, James T. (1996) & Sociological & Feminine use of public space. & Use of bars by women in Nigeria. \\
\hline Buck, Lori, et al. (1998) & Political economy & $\begin{array}{l}\text { Study of sanctions from a } \\
\text { gender perspective. }\end{array}$ & $\begin{array}{l}\text { Analysis of the case of international sanctions } \\
\text { against Iraq and its specific impact on gender. }\end{array}$ \\
\hline Henley, Nancy M., et al. (1998) & Psychometric & Scale construction. & $\begin{array}{l}\text { Development of a scale to measure diverse } \\
\text { feminist attitudes. }\end{array}$ \\
\hline Burns, Linda (1998) & Sociological & Analysis of rape cases & $\begin{array}{l}\text { Distinction among legal and psychoanalytic } \\
\text { discourse over rape. }\end{array}$ \\
\hline Sebrant, Ulla (1999) & $\begin{array}{l}\text { Feminist work } \\
\text { Psychology }\end{array}$ & $\begin{array}{l}\text { Situation of women in } \\
\text { hierarchical organizations of } \\
\text { feminized health }\end{array}$ & $\begin{array}{l}\text { More flexible and less authoritarian organizations } \\
\text { favor feminine development. }\end{array}$ \\
\hline Yohei, Murata (2000) & Social Psychology & Masculine alienation. & $\begin{array}{l}\text { Single adult men suffer because of recent changes } \\
\text { in gender roles. }\end{array}$ \\
\hline Im, Eun Ok (2001) & $\begin{array}{l}\text { Meta-analysis } \\
\text { of feminist nursing }\end{array}$ & Physical activity of women. & $\begin{array}{l}\text { Critical revision of literature that does not } \\
\text { consider women experiences. }\end{array}$ \\
\hline Wallace, Michelle (2001) & $\begin{array}{l}\text { Organization } \\
\text { analysis }\end{array}$ & $\begin{array}{l}\text { Work training of women and } \\
\text { power relations. }\end{array}$ & $\begin{array}{l}\text { Opportunities for women in the lowest strata of } \\
\text { work ladder were analyzed. }\end{array}$ \\
\hline $\begin{array}{l}\text { Schmied, Virginia A., et al. } \\
\text { (2001) }\end{array}$ & $\begin{array}{l}\text { Feminist } \\
\text { postestructuralistic } \\
\text { Psychology }\end{array}$ & Body image during pregnancy. & $\begin{array}{l}25 \text { first time mothers were interviewed over } \\
\text { their confusions on the boundaries between their } \\
\text { bodies and their fetus. }\end{array}$ \\
\hline Peckover, Sue (2002) & $\begin{array}{l}\text { Social Psychology } \\
\text { Feminist } \\
\text { postestructuralist }\end{array}$ & $\begin{array}{l}\text { Care and functions of British } \\
\text { sanitary inspection. }\end{array}$ & $\begin{array}{l}\text { Support/monitoring provided by } 24 \text { sanitary } \\
\text { visitors towards } 16 \text { women victims of domestic } \\
\text { violence is discussed. }\end{array}$ \\
\hline Dempsey, Ken (2002) & Social Psychology & $\begin{array}{l}\text { Who benefits more with } \\
\text { marriage? }\end{array}$ & $\begin{array}{l}\text { Interviews of } 45 \text { wives and } 40 \text { husbands explore } \\
\text { the bias benefits in favor of men and factors that } \\
\text { mediate the negotiation among actors. }\end{array}$ \\
\hline Ditz, Toby L. (2004) & Historical & $\begin{array}{l}\text { Male history is viewed through } \\
\text { the power of gender. }\end{array}$ & $\begin{array}{l}\text { Analysis of the history of masculinity in the } \\
\text { British colonies in America is done through the } \\
\text { lenses of gender inequality. }\end{array}$ \\
\hline
\end{tabular}


Table 2 (continued)

Focus, themes, and results from analyzed empirical articles with feminist perspective.

\begin{tabular}{|c|c|c|c|}
\hline First author (year) & Focus & Central theme & Conclusions \\
\hline $\begin{array}{l}\text { Peter, Elizabeth H., et } \\
\text { al. (2004) }\end{array}$ & Sociological & $\begin{array}{l}\text { Impact on the labor environment } \\
\text { over nurses' health }\end{array}$ & $\begin{array}{l}\text { Analysis of burnout of Canadian nurses using } \\
\text { the methodology of Margaret Urban Walker and } \\
\text { development of } 4 \text { categories. }\end{array}$ \\
\hline $\begin{array}{l}\text { Laitinen, Irmeli, et al. } \\
\text { (2004) }\end{array}$ & Sociological & $\begin{array}{l}\text { Feminist activism and self-help } \\
\text { groups in the Finish movement. }\end{array}$ & $\begin{array}{l}\text { Study of Finish women's depression as a result of } \\
\text { gender tensions in a friendly State for female health. }\end{array}$ \\
\hline $\begin{array}{l}\text { Oliveira, Dora Lucia, et } \\
\text { al. (2004) }\end{array}$ & $\begin{array}{l}\text { Feminist Psycholpogy } \\
\text { posestructuralist }\end{array}$ & $\begin{array}{l}\text { Campaigns to prevent AIDS } \\
\text { among female workers }\end{array}$ & $\begin{array}{l}\text { The logic promoting negotiations for safe sex } \\
\text { reproduces hegemonic representations of inequity. }\end{array}$ \\
\hline $\begin{array}{l}\text { Cross, Patricia A. , et al. } \\
(2006)\end{array}$ & Clinical Psychology & To understand sadomasochism. & $\begin{array}{l}4 \text { approaches to sadomasochism are examined } \\
\text { showing that power relations explain } \\
\text { sadomasochism, and that it is not a matter of } \\
\text { inflicting and receiving pain. }\end{array}$ \\
\hline $\begin{array}{l}\text { Clayton, Ben, et al. } \\
(2006)\end{array}$ & Sociological & $\begin{array}{l}\text { Behavior of football soccer } \\
\text { college female players. }\end{array}$ & $\begin{array}{l}\text { From the analysis of conversations with athletes } \\
\text { over } 3 \text { themes, masculine identity is described from } \\
\text { a feminist perspective. }\end{array}$ \\
\hline Robson, Elsbeth (2006) & Ethno sociology & $\begin{array}{l}\text { The kitchen as a feminine space } \\
\text { in a rural villa in Nigeria. }\end{array}$ & $\begin{array}{l}\text { Analysis of feminine activities in the private } \\
\text { domestic space of polygamous families (multiple } \\
\text { wives). }\end{array}$ \\
\hline $\begin{array}{l}\text { Wood, Mitchell J. } \\
\text { (2006) }\end{array}$ & Sociological & $\begin{array}{l}\text { Body image alterations and } \\
\text { gender oppression among } \\
\text { homosexual men. }\end{array}$ & $\begin{array}{l}\text { Aesthetic analysis of beauty on the light of } \\
\text { postmodern queer feminism. }\end{array}$ \\
\hline $\begin{array}{l}\text { Obando Salazar, Olga } \\
(2006)\end{array}$ & Psychopedagogic & $\begin{array}{l}\text { Labor of young women } \\
\text { suffering racial discrimination. }\end{array}$ & $\begin{array}{l}\text { Psychopedagogic proposal for a program to raise } \\
\text { antiracial consciousness for young Colombian } \\
\text { women. }\end{array}$ \\
\hline Few, April L. (2007) & Sociological & $\begin{array}{l}\text { Comparison of the feminist } \\
\text { black theories and the critical } \\
\text { racial theory. }\end{array}$ & $\begin{array}{l}\text { Integration of both theoretical approaches is } \\
\text { suggested for studying the life of Afro American } \\
\text { women. }\end{array}$ \\
\hline Herzog, Sergio (2007) & Psychometric & $\begin{array}{l}\text { Public perception of sexual } \\
\text { harassment. }\end{array}$ & $\begin{array}{l}\text { Results from a survey to } 630 \text { citizens of Israel on } \\
\text { factors affecting sexual harassment. }\end{array}$ \\
\hline $\begin{array}{l}\text { Da Silva, Susana, M.V., } \\
\text { et al. (2007) }\end{array}$ & Political geography & $\begin{array}{l}\text { Emerging gender geography in } \\
\text { Latin America. }\end{array}$ & Brazil and Argentina were at the top. \\
\hline $\begin{array}{l}\text { Rocheleau, Dianne E. } \\
(2008)\end{array}$ & Political Ecology & $\begin{array}{l}\text { Comparative critical analysis } \\
\text { of different postures in political } \\
\text { ecology. }\end{array}$ & $\begin{array}{l}\text { The biophysics and socioeconomic observation of } \\
\text { phenomena, differences between political ecology } \\
\text { from first and second generation. }\end{array}$ \\
\hline $\begin{array}{l}\text { Jones, Lani V., et al. } \\
\text { (2008) }\end{array}$ & Social Work & $\begin{array}{l}\text { Depression among Afro } \\
\text { American women. }\end{array}$ & $\begin{array}{l}\text { More interventions were required applying culturally } \\
\text { relevant approaches with a feminist perspective. }\end{array}$ \\
\hline Herzog, Sergio (2008) & Psychometric & $\begin{array}{l}\text { Traffic of women for } \\
\text { prostitution. }\end{array}$ & $\begin{array}{l}\text { A survey conducted in Israel documents the public } \\
\text { consideration that government should focus on } \\
\text { ending this type of women slavery. }\end{array}$ \\
\hline $\begin{array}{l}\text { Yick, Alice G., et al. } \\
(2008)\end{array}$ & Meta-analysis & $\begin{array}{l}\text { Longitudinal examination of } \\
\text { domestic violence between } \\
\text { Asian and Asian-American }\end{array}$ & $\begin{array}{l}60 \text { articles were analyzed published along } 16 \\
\text { years on the theme, focusing mainly on immigrant } \\
\text { communities from India. }\end{array}$ \\
\hline Mazur, Amy G. (2008) & Sociological & $\begin{array}{l}\text { Influence of feminism on } \\
\text { generation of public policies. }\end{array}$ & $\begin{array}{l}\text { A comparative theoretical and methodological } \\
\text { analysis is offered for measuring this impact. }\end{array}$ \\
\hline $\begin{array}{l}\text { Bashevkin, Sylvia } \\
\text { (2009) }\end{array}$ & Political Science & $\begin{array}{l}\text { Feminist Analysis of feminist } \\
\text { discourse of Canadian women } \\
\text { leaders along a } 12 \text { year period. }\end{array}$ & $\begin{array}{l}\text { Feminist discourse of women candidates to public } \\
\text { posts was more likely from left wing orientations } \\
\text { and from weak opposition parties. }\end{array}$ \\
\hline Ferguson, Lucy (2010) & Political Science & $\begin{array}{l}\text { Meaning of the term "gender" in } \\
\text { the programs of touristic micro } \\
\text { enterprises }\end{array}$ & $\begin{array}{l}\text { Political discourse departs from central concepts } \\
\text { of feminist theories and this type of project fails } \\
\text { in incorporating indigenous women for touristic } \\
\text { development. }\end{array}$ \\
\hline
\end{tabular}


Table 2 (continued)

Focus, themes, and results from analyzed empirical articles with feminist perspective.

\section{First author (year)}

Kalviknes Bore, Inger L. (2010)

Hofbauer, Johanna (2010) Sociological

Ergün, Emek (2010) Sociolinguistic

Plummer, Marilyn, et al. (2010)

Oberhauser, Ann M. (2010)

Motulsky, Sue L. (2010)

Fardon, Jill, et al. (2010)

Rose, Donald N., et al. (2011)

Singh, Devendra, N., et al. (2011)

Holmberg, Tora (2011)

Newmahr, Staci (2011)

Shea, Jennifer M., et al. (2012)

Selwyn, Neil (2012)

Marlow, Susan, et al. (2012)

Bilić, Bojan (2012)

Mínguez, Almudena M. (2012)

Falender, Carol A., et al. (2013)

Psychological

feminist

Historic

Feminist

feminism

Sociological

Management

Sociological
Central theme

Gender distinctions are built from TV soap operas

Social inequity and symbolic domination.

To connect the fields of feminist sociolinguistics with studies of feminist translation.

Epistemological affinity between feminist research and solid theory.

Sociological feminist Resistance against neolibera globalization.

Change of career among adult women.

poststructuralist

Gender bias in historical texts

Forensic Nursing

Respect in the relationship nurse-patient.

Feminine beauty in different cultures and the relation beautyhealth.

Animal care and "dying well"

Social Psychology Voluntarily taking risks.

Social Psychology Dominant discourse on

poststructuralist

Entrepreneurial incubation

Political Science

Activist movement in Belgrade for "the women in black"

Gender and care.

Social Psychology Clinical supervision.
Conclusions

British and Norwegian TV audiences were studied to determine the attraction power by sexes to types of programs

Pierre Bourdieu's analytical categories are used to comprehend exclusion of women from modern organizations.

Sexist language and the use of generic male are revised. Forms of interdisciplinary dialogues are suggested.

The study of marginalized women could be enriched with the inputs of feminist theory in 6 spheres.

Analysis of the way gender models the relationship between global process and local strategies in Ghana.

Relational processes affect decision making for women undergoing a career change.

A deconstructive methodology is offered for deconstructing realist historic narrative in South Africa that makes women invisible.

"Respect" is discussed as an ethical practice of the nurse focusing on the care for criminals, based upon the analysis of interviews to 15 nurses in rehabilitation units.

Compatibility of evolutive and feminist perspectives is discussed in the development of the concept of beauty based upon the ratio waist to hips.

"Mortal love" towards the animals is discussed from a feminist perspective.

A deconstruction of the concept of bordeline job is offered for explaining taking risks willingly in sadomasochist communities.

15 young immigrants residents of Canada were interviewed to figure out the influence of socioeconomic aspects over their discourses.

Inputs from 4 theories on social construction of technology and domestication of digital technology in formal and informal education are discussed.

Gender roles attributions in the experience of entrepreneurial women in high technology business reproduce dominant stereotypes.

Explanations are offered for the permanence of this small anti patriarchal and antiwar group for the last 20 years.

Attempt to quantify informal work in relationship with gender equity in developed countries.

Definition of effective practices, feminist approach and multicultural methodology. 